\title{
Atrazine and nicosulfuron affect the reproductive fitness of the predator Podisus nigrispinus (Hemiptera: Pentatomidae)
}

\author{
TATIANE C. REIS ${ }^{1}$, MARCUS A. SOARES ${ }^{1}$, JOSÉ B. DOS SANTOS ${ }^{1}$, CONCEIÇÃO A. DOS \\ SANTOS $^{2}$, JOSE EDUARDO SERRÃO ${ }^{3}$, JOSÉ C. ZANUNCIO ${ }^{4}$ and EVANDER A. FERREIRA ${ }^{1}$ \\ ${ }^{1}$ Departamento de Agronomia, Universidade Federal dos Vales do Jequitinhonha e Mucuri/ \\ UFVJM, Campus JK, Rodovia MGT 367, 39100-000 Diamantina, MG, Brazil \\ ${ }^{2}$ Departamento de Ciências Biológicas e da Saúde, Universidade Federal dos Vales do Jequitinhonha \\ e Mucuri/UFVJM, Campus JK, Rodovia MGT 367, 39100-000 Diamantina, MG, Brazil \\ ${ }^{3}$ Departamento de Biologia Geral, Universidade Federal de Viçosa, Av. PH Rolfs, \\ s/n, Campus Universitário, 36570-000 Viçosa, MG, Brazil \\ ${ }^{4}$ Departamento de Biologia Animal, Universidade Federal de Viçosa, Av. PH Rolfs, \\ s/n, Campus Universitário, 36570-000 Viçosa, MG, Brazil
}

Manuscript received on November 6, 2017; accepted for publication on May 21, 2018

\begin{abstract}
Herbicides can impact non-target metabolic pathways in natural enemies and lead to the reduction of these populations in the field. Behavioral characteristics, morphology and histology of reproductive structures and reproduction of females of Podisus nigrispinus (Dallas) (Hemiptera: Pentatomidae) were evaluated under the effect of the herbicides atrazine, nicosulfuron and the mixture of both. The number of mature oocytes per ovary was lower in females exposed to the herbicides atrazine, nicosulfuron and the mixture of both. Herbicides did not affect the longevity and mortality of P. nigrispinus, therefore, they are selective for this predator. On the other hand, herbicides can cause sublethal effects by affecting the reproduction of predators.
\end{abstract}

Key words: behavior, histology, morphology, reproduction, herbicides.

\section{INTRODUCTION}

Weeds are for many beneficial insects, the first source of resources (Norris and Kogan 2000, Msebah and El-Husseini 2009, Camilo et al. 2016). This situation exposes these insects to herbicides by direct contact or ingestion of prey and sap of contaminated plants (Marshall et al. 2003, Mahdian et al. 2007, Cloyd and Bethke 2011, de Castro et al. 2013). Herbicides can cause interference

Correspondence to: Marcus Alvarenga Soares

E-mail: marcus.alvarenga@ufvjm.edu.br in metabolic pathways of insects and alter their reproductive capacity and population dynamics (Menezes et al. 2012, Souza et al. 2014).

Hemiptera predators occur naturally in several agroecosystems. Podisus nigrispinus (Dallas) (Hemiptera: Pentatomidae) is a natural enemy of more than 30 pests (Zanuncio et al. 2003, Freitas et al. 2006, Torres et al. 2006). In addition, it is possible to reduce insecticides with releases of this natural enemy (Lacerda et al. 2004, Lundgren 2011, de Jesus et al. 2014). 
Herbicides limit the permanence of the natural enemy in the environment (Menezes et al. 2012) caused by changes in behavior and interference in female's fitness (Torres et al. 2006, Desneux et al. 2007, Msebah and El-Husseini 2009, Martinou et al. 2014). However, the effects of these agrochemicals on insects tend to reduce the ability of these agents to control pests in the field (Carmo et al. 2010, Menezes et al. 2012).

The objective of this work was to evaluate the ecotoxicological effects of herbicides used in corn crop, by studying the behavioral characteristics, morphology and histology of the reproductive structures and reproduction of females of $P$. nigrispinus predators.

\section{MATERIALS AND METHODS}

\section{OBTAINING FEMALES OF Podisus nigrispinus}

The $P$. nigrispinus eggs, coming from the rearing of the Laboratory of Biological Control of Insects (LCBI) of the Federal University of the Jequitinhonha and Mucuri Valleys (UFVJM), where this predator was maintained at $25 \pm 2{ }^{\circ} \mathrm{C}, 70 \pm 10 \%$ relative humidity and photoperiod of 12 hours.

Two hundred eggs with about 24 hours were collected and placed in $500 \mathrm{~mL}$ plastic pots with moistened cotton. In the third stage, the nymphs of P. nigrispinus were separated into groups of five.

Throughout the experiment, nymphs and adults of this predator were fed with pupae of Tenebrio molitor (Linnaeus) (Coleoptera: Tenebrionidae) ad libitum from LCBI of UFVJM. Adults of $P$. nigrispinus were sexed by the external appearance of the genitalia on the day of the emergence.

\section{COMPOSITION OF TREATMENTS}

The treatments were arranged in a completely randomized design with fifteen replicates for the herbicide atrazine (Primoleo ${ }^{\circledR} 400 \mathrm{~g}$ ia / L), fifteen for nicosulfuron (Sanson ${ }^{\circledR} 40 \mathrm{~g}$ ia / L), fifteen for the mixture (atrazine (Primoleo ${ }^{\circledR} 400 \mathrm{~g}$ ia / L)
+ nicosulfuron (Sanson ${ }^{\circledR} 40 \mathrm{~g} / \mathrm{L}$ )) and a control sample (distilled water).

\section{APPLICATION OF TREATMENTS}

Fifteen females of $P$. nigrispinus, four days old, were individualized in $500 \mathrm{~mL}$ plastic pots and lined with corn leaves, to avoid contact with excess product in the treatments. A $1 \mathrm{~mL}$ syringe with a needle adapted for spraying was used in each pot, in order to spray directly in the female. According to each treatment, the syringe was filled with $0.26 \mathrm{~mL}$ of solution with atrazine $\left(12 \mathrm{gL}^{-1}\right)$; nicosulfuron $(0.3$ $\mathrm{gL}^{-1}$ ); the mixture (atrazine $12 \mathrm{gL}^{-1}+$ nicossulfuron $\left.0.3 \mathrm{gL}^{-1}\right)$; or $0.26 \mathrm{~mL}$ of distilled water, as a control (herbicide free) (Menezes et al. 2012). The concentrations were calculated basing on pot area $\left(0.016 \mathrm{~m}^{2}\right)$ and commercial recommendation, being $6 \mathrm{Lha}^{-1}$ of Primóleo ${ }^{\circledR}$ (400 $\mathrm{gL}^{-1}$ of atrazine) and $1.5 \mathrm{Lha}^{-1}$ of Sanson ${ }^{\circledR}$ (40 $\mathrm{gL}^{-1}$ of nicosulfuron). After six hours, the time required for herbicide to penetrate corn leaves, females of $P$. nigrispinus were individualized in Petri dishes $(10 \mathrm{~cm})$ with a male of this predator.

\section{COPULA BEHAVIOR}

After application of treatments, couples of $P$. nigrispinus were maintained individually in Petri dishes, in a completely randomized design with fifteen replicates. The predisposition of females to copulation and the copulation duration of this predator were observed for 24 hours. After this period, the longevity and fertility of the females was evaluated. The data were submitted to analysis of variance and compared by the Tukey Test at 5\% probability with software $\mathrm{R}$.

\section{MORPHOLOGICAL ANALYSIS}

Seven days after its emergence, three females of $P$. nigrispinus per treatment were dissected in saline solution at the Laboratory of Histology of the UFVJM. The development and maturation of oocytes by ovaries was observed, as well as the 
numbers of mature and immature oocytes by ovaries of this predator were counted (Soares et al. 2011). The ovaries of $P$. nigrispinus were photographed with a 16.1 megapixel digital camera coupled to a stereoscopic microscope. After extraction, the ovaries of this predator were transferred immediately to Bouwin fixative solution for 24 hours in environment temperature.

\section{HISTOLOGICAL ANALYSIS}

After fixation, the ovaries of $P$. nigrispinus were dehydrated in increasing series of ethanol and included in HistoResin (Leica). Subsequently, the samples were sectioned at $5 \mu \mathrm{m}$ and stained in aqueous hematoxylin and eosin solution. Sections were analyzed and photographed under an optical microscope. Histological studies were performed with three individuals per treatment.

\section{REPRODUCTION OF Podisus nigrispinus}

Twelve couples by treatment were chosen randomly of the test of copula behavior and were maintained to evaluate the longevity of females, periods of pre-oviposition, oviposition and post-oviposition, number of eggs per treatment, and fecundity (total viable eggs). The data were submitted to analysis of variance and compared by the Tukey Test at 5\% with software R.

\section{RESULTS}

\section{COPULA BEHAVIOR}

The predisposition of females to copulation was similar in treatments with the isolated herbicides. Of the females exposed to the mixture (atrazine and nicosulfuron), only $13 \%$ presented predisposition to copula after 11 hours.

The longevity (15.0 to 22.08 days) and the copulation duration (10 to 15 hours) were not altered by the effect of the isolated herbicides or the mixture (Table I).
MORPHOLOGY OF THE OVARIES OF Podisus nigrispinus

The morphology of the reproductive system of $P$. nigrispinus females did not differ between treatments. Regardless of the treatment, each ovary of $P$. nigrispinus had seven ovarioles, joining through the terminal filaments and forming a compact bundle-shaped structure (Fig. 1).

Herbicides reduced the number of mature oocytes of $P$. nigrispinus females. The increase in the maturation period of the oocytes interfered with the number of eggs per female, but not with the viability (Table II). A compact mass of fat body was observed in the reproductive tract of $P$. nigrispinus females exposed to the herbicides, which was not observed in the control sample (Fig. 1).

\section{HISTOLOGY OF THE OVARIES OF Podisus nigrispinus}

The herbicides atrazine, nicosulfuron and the mixture of both, did not alter the cells of the tissues of the ovaries of $P$. nigrispinus. The ovaries presented the intrinsic characteristics of a telotrophic meroistic ovary type, with each ovary was presented morphologically divided into terminal filament, trophic (nourishing chamber), vitellary and pedicel (Fig. 2a).

Oocytes undergo morph-functional changes in the vitellary, resulting in complete development or maturation of the eggs. The oocytes follow through

TABLE I

Number of females (No.), longevity (Long. (days)), duration of copulation (Dur. (hours) (day \pm standard deviation) and number of females mated in $\mathbf{2 4}$ hours (Mated (\%)) of Podisus nigrispinus (Hemiptera: Pentatomidae) exposed to atrazine and nicosulfuron.

\begin{tabular}{cccc}
\hline Treatment & Long. (days) & Dur. (hours) & $\begin{array}{c}\text { Mated } \\
\mathbf{( \% )} .\end{array}$ \\
\hline Control & $22.08 \pm 11.41 \mathrm{a}$ & $13.8 \pm 4.15 \mathrm{a}$ & $83 \% \mathrm{a}$ \\
Atrazine & $15.00 \pm 8.34 \mathrm{a}$ & $15.14 \pm 2.26 \mathrm{a}$ & $58 \% \mathrm{a}$ \\
Nicosulfuron & $22.08 \pm 8.81 \mathrm{a}$ & $11.1 \pm 4.14 \mathrm{a}$ & $83 \% \mathrm{a}$ \\
Mixture & $18.75 \pm 10.21 \mathrm{a}$ & $10.0 \pm 9.89 \mathrm{a}$ & $13 \% \mathrm{~b}$ \\
\hline
\end{tabular}

Means followed by the same letter in the columns do not differ according to the Tukey Test at $5 \%$ probability. 

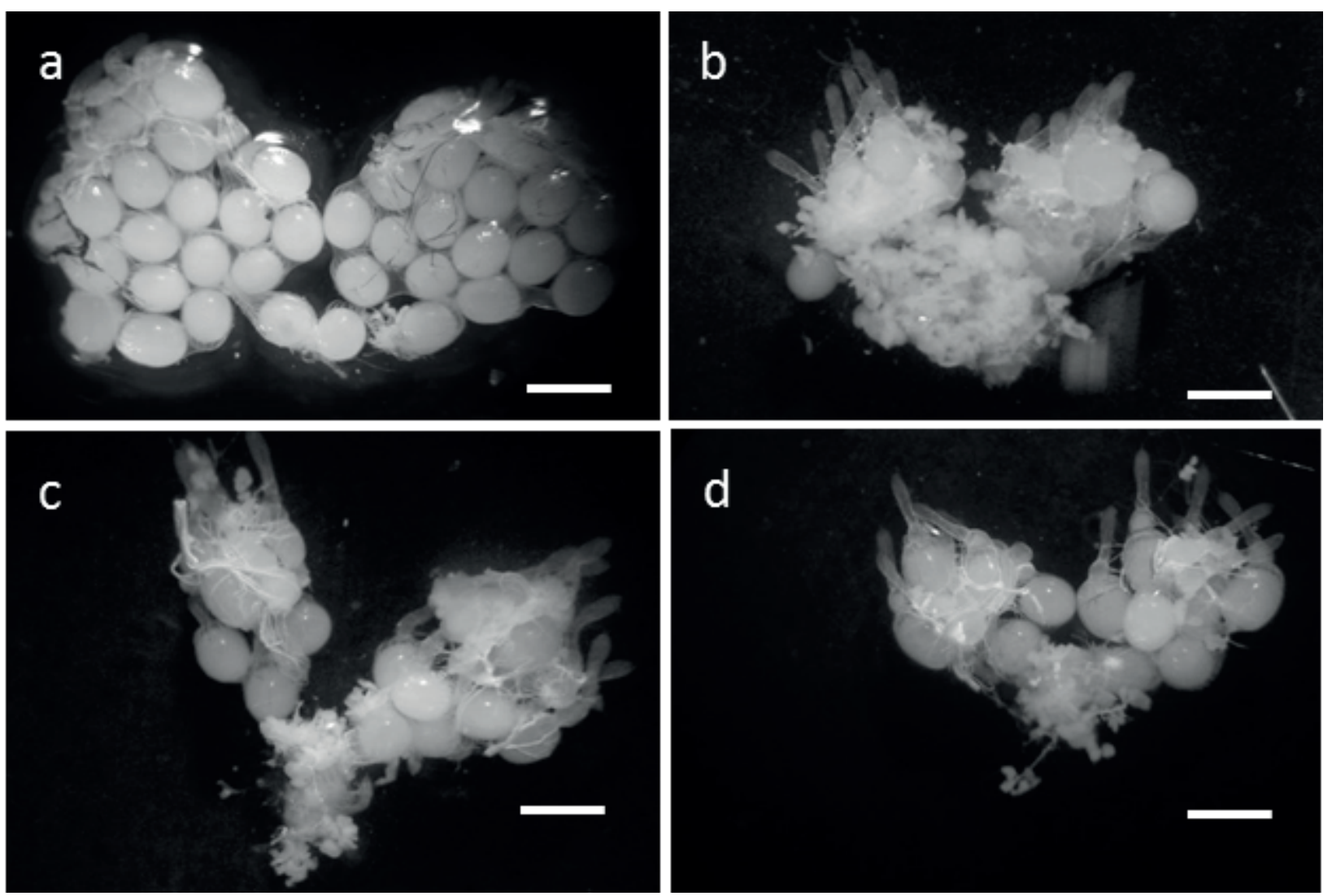

Figure 1 - Ovary of Podisus nigrispinus (Hemiptera: Pentatomidae) in treatments: control sample (a), atrazine (b), mixture (atrazine + nicosulfuron) $(\mathbf{c})$, nicosulfuron $(\mathbf{d})$. Bars $=2 \mathrm{~mm}$.

the processes of vitellogenesis and choriongenesis, in a linear arrangement, with the more developed ones presenting an increase in volume and a greater amount of vitellogenic reserves (Fig. 2b).

The germ cell (Fig. 2c) is the site of division and differentiation where the formation of cysts occurs (a group of differentiated germ cells), from which the trophocytes and oocytes originate with the somatic cells, forming the ovarian follicles.

Follicular cells surround the oocytes in a single layer (Fig. 2d). The cells of the surrounding layer exhibit an interruption represented by nutrient channels to the oocytes. Oocytes at an advanced stage of development, with more compact follicular cells and greater thickness due to their growth were observed in all treatments (Fig. 2d). The metabolism of follicular cells intensified during the vitellogenesis process evidenced by the follicle cells at different stages of development (Fig. 2e). The follicular cell death was not observed in the ovarioles of females exposed to the herbicides.

\section{REPRODUCTIVE CHARACTERISTICS}

The pre-oviposition period was higher with nicosulfuron (Table II). The oviposition and postoviposition periods and egg viability were similar between treatments (Table II). The number of eggs per female was higher in the control sample than in the treatments with the herbicides (Table II).

\section{DISCUSSION}

The knowledge on oogenesis in natural enemies is important for the applied biological control (Andrade et al. 2012). There are few studies on the effects of agrochemicals on the behavior and reproductive structures of Podisus spp. females 

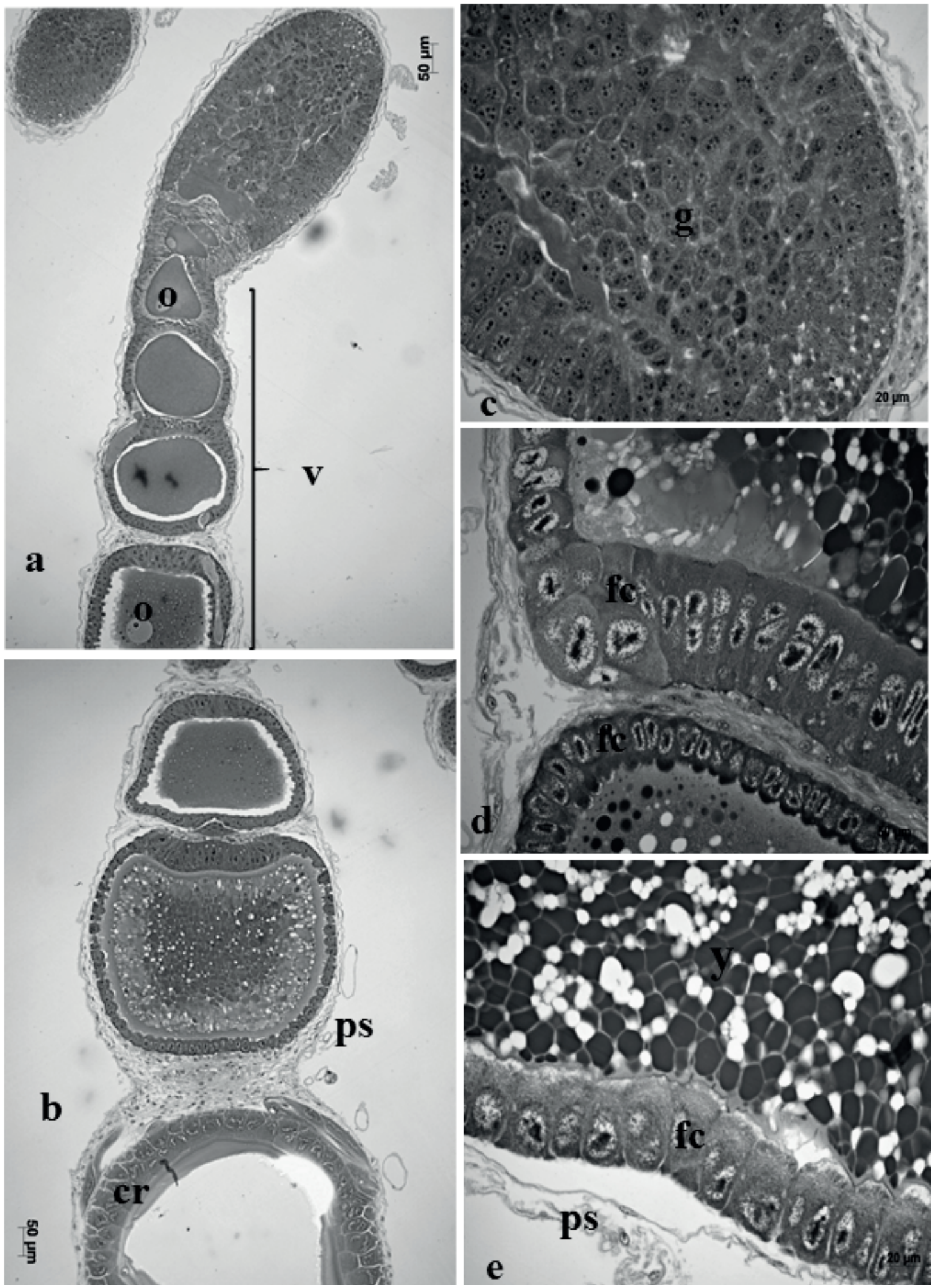

Figure 2 - Longitudinal cut of the ovariole of the predator Podisus nigrispinus (Heteroptera: Pentatomidae) with oocytes at different stages of development. a, b) oocytes at different stages of development and linear arrangement. c) Germ region. d, e) Details of follicle cells at different stages of development. g, germ; o, oocyte; v, vitellary; fc, follicle cells; $\mathbf{y}$, gem; ps, peritoneal layer; cr, corion. 
TABLE II

Pre-oviposition (Pre), post-oviposition (Post), oviposition (Ovip.) periods in days and the number of eggs per female (No.) and the numbers of mature (Mat.) and immature (Imat.) oocytes and the viability of eggs (Viab.) (\%) of Podisus nigrispinus (Heteroptera: Pentatomidae) in the control sample (Cont.) and the samples exposed to atrazine (Atraz.), nicosulfuron (Nicos.) or a mixture of these herbicides (Mixt.).

\begin{tabular}{cccccccc}
\hline Treat. & Pre. & Post. & Ovip. & No. & Mat. & Imat. & Viab. \\
\hline Cont. & $4.67 \pm 2.45 \mathrm{a}$ & $5.44 \pm 2.40 \mathrm{a}$ & $16.67 \pm 9.68 \mathrm{a}$ & $173.0 \mathrm{a}$ & $25.0 \pm 5.19 \mathrm{a}$ & $9.33 \pm 3.78 \mathrm{a}$ & $76 \mathrm{a}$ \\
Atraz. & $7.22 \pm 4.41 \mathrm{a}$ & $2.33 \pm 2.50 \mathrm{a}$ & $8.22 \pm 3.63 \mathrm{a}$ & $74.5 \mathrm{~b}$ & $3.33 \pm 2.88 \mathrm{~b}$ & $14.0 \pm 3.60 \mathrm{a}$ & $62 \mathrm{a}$ \\
Nicos. & $8.60 \pm 2.67 \mathrm{~b}$ & $4.00 \pm 2.40 \mathrm{a}$ & $13.00 \pm 7.85 \mathrm{a}$ & $92.8 \mathrm{~b}$ & $5.67 \pm 5.93 \mathrm{~b}$ & $11.3 \pm 1.53 \mathrm{a}$ & $71 \mathrm{a}$ \\
Mixt. & $6.90 \pm 2.38 \mathrm{a}$ & $1.7 \pm 2.36 \mathrm{a}$ & $12.10 \pm 9.52 \mathrm{a}$ & $81.2 \mathrm{~b}$ & $7.33 \pm 6.42 \mathrm{~b}$ & $13.33 \pm 2.08 \mathrm{a}$ & $72 \mathrm{a}$ \\
\hline
\end{tabular}

Means per column followed by the same letter do not differ according to the Tukey Test at $5 \%$ probability.

Pentatomidae predators with potential for use in integrated pest management - MIP (Desneux et al. 2007, Lundgren 2011).

The effects of the herbicides in this study on the copulation behavior of $P$. nigripinus females were more evident in the first 24 hours with the herbicide mixture, reducing the copula. The use of agrochemicals can affect the chemical communication between arthropods, reducing their predatory instinct and the ability to locate their partners (He et al. 2012, de Castro et al. 2012). The juvenile hormone affects the overall metabolism in most insects, causing changes in histogenesis, polymorphism types and sexual behavior (Griesinger et al. 2011, He et al. 2012). This effect may indicate adaptive behavior, with females exhibiting less mobility (and copulation behavior) to reduce exposure to toxic wastes (Campos et al. 2011). However, lower mobility may increase the vulnerability to others natural enemies in the field (Kunkel et al. 2001). Imidacloprid benefited the mobility of beneficial arthropods, but with different effects over time (Suchail et al. 2001) according to the dose of this compound (Desneux et al. 2007). This shows that the exposure of organisms to agrochemicals can provoke physiological and biochemical responses, including detoxification or metabolism of the product by enzymes (Oliveira et al. 2012).

The predisposition to copulation of the females exposed to the isolated herbicides suggests tolerance to the isolated application and indicates interactions among the active principles of the herbicides in the treatment composed by the mixture. These interactions may be toxicokinetic and toxicodynamic (Anderson and Lydy 2002). Moreover, the interaction of herbicide formulation chemicals, such as solvents, surfactants and wetting agents, can modify the effect of the herbicide acid equivalent on organisms and explain this behavior (Malkomes 2000, Santos et al. 2004).

The similar copulation duration in the first 24 hours in the different treatments shows that the herbicides should not have affected the gain in genetic and nutritional material of the females by males. The copula of $P$. nigrispinus has a mean duration of 12 hours, time related to the amount of transferred material (Carvalho et al. 1994, Soares et al. 2011) by the male to ensure that its gametes migrate to the spermatheca (Chapman et al. 2000). Agrochemicals trigger distinct responses in $P$. nigrispinus females, since azadirachtin increased the duration of the copula period and the transfer of materials to females (Oliveira et al. 2012).

The longevity of $P$. nigrispinus females varies with prey and environmental conditions. Nymphs of this predator were more vulnerable to these agrochemicals, with less survival until the fourth stage (Menezes et al. 2012). Females of this predator can present longevity around 34 days in satisfactory conditions (Torres et al. 2006). 
The morphological and histological similarity of $P$. nigrispinus ovaries in all treatments showed ovarioles with oocytes in continuous development. Each ovariole of the same ovary presents a similar stage of development (Büning 1994, Lemos et al. 2005). The lower number of mature oocytes in females exposed to herbicides, isolated or in combination, hypothesizes the side effects of these compounds on the juvenile hormone $(\mathrm{JH})$, leading to the accumulation of pre-vitellogenic oocytes (Davey 2000). The absence of the JH can affect the spaces between the follicular cells, not allowing greater deposition of vitellogenin. However, oogenesis is reestablished by normalization of the JH supply (Kotaki 1996, Davey 2000, 2007). The observation of the fat body compact mass tissue in the ovaries of $P$. nigrispinus hypothesizes a greater activity in the production of the fatty tissue to detoxification of the organism. Thus, the $P$. nigrispinus fat body being used for detoxification of herbicides could also reduce the production of vitellogenin in the maturation of the oocytes. The synthesis of vitellogenin is controlled by the $\mathrm{JH}$ and has action stimulated by the fat body (Davey 2007).

The highest pre-oviposition period of $P$. nigrispinus with nicosulfuron shows an impact on this predator as observed for Supputius cincticeps (Stål) (Hemiptera: Pentatomidae) exposed to sublethal concentrations of permethrin (Lemos et al. 2005). The tolerance of Asopinae to agrochemicals has been attributed to the lower penetration rate of these products in the cuticle of these predators or their rapid metabolization (Yu 1988).

The $P$. nigripinus females maintained copula behavior, maturation of their oocytes and reproduction with the herbicides atrazine, nicosulfuron and the mixture of both, but with lower values. Physiological changes in the reproductive parameters of $P$. nigrispinus, with less reproduction in the presence of the herbicides, show the impact of the herbicides on the coordination between the nervous and hormonal systems of insects, with physiological and behavioral events related to oviposition.

Agrochemicals compatible with MIP have been selected with mortality tests. However, the sublethal impact of these compounds on the population of $P$. nigrispinus can be better evaluated, as well as methods that this predator uses to ensure their survival.

\section{ACKNOWLEDGMENTS}

The authors would like to thank the Conselho Nacional de Desenvolvimento Científico e Tecnológico (CNPq), Coordenação de Aperfeiçoamento de Pessoal de Nível Superior (CAPES) and the Fundação de Amparo à Pesquisa do Estado de Minas Gerais (FAPEMIG) for financial support.

\section{REFERENCES}

ANDERSON TD AND LYDY MJ. 2002. Increased toxicity to invertebrates associated with a mixture of atrazine and organophosphate insecticides. Environ Toxicol Chem 21: 1507-1514

ANDRADE GS, SOUSA AH, SANTOS JC, GAMA FC, SERRÃO JE AND ZANUNCIO JC. 2012. Oogenesis pattern and type of ovariole of the parasitoid Palmistichus elaeisis (Hymenoptera: Eulophidae). An Acad Bras Cienc 84: 767-774.

BÜNING J. 1994. The ovary of Ectognatha, the Insecta s.str. In: Büning J (Ed), The insect ovary: ultrastructure, previtellogenic growth and evolution. London: Chapman \& Hall, p. 281-299.

CAMPOS MR, PICANÇO MC, MARTINS JC, TOMAZ AC AND GUEDES RNC. 2011. Insecticide selectivity and behavioral response of the earwig Doru luteipes. Crop Prot 30: $1535-1540$.

CAMILO SS, SOARES MA, LEITE GLD, SANTOS JB, ASSIS JUNIOR SL AND ZANUNCIO JC. 2016. Do floral resources in Eucalyptus plantations affect fitness parameters of the parasitoid Palmistichus elaeisis (Hymenoptera: Eulophidae)? Phytoparasitica 44: 651-659.

CARMO EL, BUENO AF AND BUENO RCOF. 2010. Pesticide selectivity for the insect egg parasitoid Telenomus remus. BioControl 55: 455-464.

CARVALHO RS, CARVALHO RS, VILELA EF, BORGES M, ZANUNCIO JC AND ALDRICH JR. 1994. Ritmo 
do comportamento de acasalamento e atividade sexual de Podisus connexivus Bergroth (Heteroptera: Pentatomidae: Asopinae). An Soc Entomol Brasil 23: 197-202.

CHAPMAN T, NEUBAUM DM, WOLFNER MF AND PARTRIDGE L. 2000. The role of male accessory gland protein Acp36DE in sperm competition in Drosophila melanogaster. Proc R Soc Lond B 267: 1097-1105.

CLOYD RAAND BETHKE JA. 2011. Impact of neonicotinoid insecticides on natural enemies in greenhouse and interior scape environments. Pest Manag Sci 67: 3-9.

DAVEY KG. 2000. The modes of action of juvenile hormones: some questions. Insect Biochem Molec 30: 663-670.

DAVEY KG. 2007. The interaction of feeding and mating in the hormonal control of egg production in Rhodnius prolixus. J Insect Physiol 53: 208-215.

DE CASTRO AA, CORRÊA AS, LEGASPI JC, GUEDES RNC, SERRÃO JE AND ZANUNCIO JC. 2013. Survival and behavior of the insecticide-exposed predators Podisus nigrispinus and Supputius cincticeps (Heteroptera: Pentatomidae). Chemosphere 93: 1043-1050.

DE CASTRO AA, ZANUNCIO TV, POLANCZYK RA, SERRÃO JE AND ZANUNCIO JC. 2012. Effect of the insect growth regulator diflubenzuron on the predator Podisus nigrispinus (Heteroptera: Pentatomidae). Ecotoxicology 21: 96-103.

DE JESUS FG, BOIÇA JÚNIOR AL, ALVES GCS AND ZANUNCIO JC. 2014. Behavior, development, and predation of Podisus nigrispinus (Hemiptera: Pentatomidae) on Spodoptera frugiperda (Lepidoptera: Noctuidae) fed transgenic and conventional cotton cultivars. Ann Entomol Soc Am 107: 601-606.

DESNEUX N, DECOURTYE A AND DELPUECH JM. 2007. The sublethal effects of pesticides on beneficial arthropods. Annu Rev Entomol 52: 81-106.

FREITAS SPC, EVANGELISTA JR WS, ZANUNCIO JC AND SERRÃO JE. 2006. Development, survival and reproduction of Podisus nigrispinus (Dallas, 1851) (Heteroptera: Pentatomidae) with salt and amino acids solution supplementary diet. Braz Arch Biol Technol 49: 449-455.

GRIESINGER LM, EVANS SC AND RYPSTRA AL. 2011. Effects of a glyphosate-based herbicide on mate location in a wolf spider that inhabits agroecosystems. Chemosphere 84: 1461-1466.

HE Y, ZHAO J, ZHENG Y, DESNEUX N AND WU K. 2012. Lethal effect of imidacloprid on the coccinellid predator Serangium japonicum and sublethal effects on predator voracity and on functional response to the whitefly Bemisia tabaci. Ecotoxicology 21: 1291-1300.

KOTAKI T. 1996. Evidence for a new juvenile hormone in a stink bug, Plautia stali. J Insect Physiol 42: 279-286.

KUNKEL BA, HELD DW AND POTTER DA. 2001. Lethal and sublethal effects of bendiocarb, halofenozide, and imidacloprid on Harpalus pennsylvanicus (Coleoptera: Carabidae) following different modes of exposure in turfgrass. J Econ Entomol 94: 60-67.

LACERDA MC, FERREIRA AMRM, ZANUNCIO TV, ZANUNCIO JC, BERNARDINO AS AND ESPINDULA C. 2004. Development and reproduction of Podisus distinctus (Heteroptera: Pentatomidae) fed on larva of Bombyx mori (Lepidoptera: Bombycidae). Braz J Biol 64: 237-242.

LEMOS WP, RAMALHO FS, SERRÃO JE AND ZANUNCIO JC. 2005. Morphology of female reproductive tract of the predator Podisus nigrispinus (Dallas) (Heteroptera: Pentatomidae) fed on different diets. Braz Arch Biol Technol 48: 129-138.

LUNDGREN JG. 2011. Reproductive ecology of predaceous Heteroptera. Biol Control 59: 37-52.

MAHDIAN K, LEEUWEN TV, TIRRY L AND DE CLERCQ P. 2007. Susceptibility of the predatory stinkbug Picromerus bidens to selected insecticides. BioControl 52: 765-774.

MALKOMES HP. 2000. Comparison of the effects of differently formulated herbicides on soil microbial activities - A review. J Plant Dis Protect 17: 781-789.

MARSHALL EJP, BROWN VK, BOATMAN ND, LUTMAN PJW, SQUIRE GR AND WARD LK. 2003. The role of weeds in supporting biological diversity within crop fields. Weed Res 43: 77-89.

MARTINOU AF, SERAPHIDES N AND STAVRINIDES MC. 2014. Lethal and behavioral effects of pesticides on the insect predator Macrolophus pygmaeus. Chemosphere 96: 167-173.

MENEZES CWG, SANTOS JB, ASSIS JÚNIOR SL, FONSECA AJ, FRANÇA AC, SOARES MA AND FERNANDES AF. 2012. Seletividade de atrazine e nicosulfuron a Podisus nigrispinus (Heteroptera: Pentatomidae). Planta Daninha 30: 327-334.

MSEBAH AH AND EL-HUSSEINI MM. 2009. Effect of weed borders on insect pests and their associated predators on sugar beet and cotton plant fields. Egypt Acad J Biolog Sci 2: 73-80.

NORRIS RF AND KOGAN M. 2000. Interactions between weeds, arthropod pests, and their natural enemies in managed ecosystems. Weed Sci 48: 94-158.

OLIVEIRA SOD, BARBOSA WF, MALQUI KSV AND GUEDES RNC. 2012. Mating behavior of the predator Podisus nigrispinus (Heteroptera: Pentatomidae) under exposure to neem. Chil J Agr Res 72: 523-527.

SANTOS JB, JACQUES RJS, PROCÓPIO SO, KASUYA MCM, SILVA AA AND SANTOS EA. 2004. Efeitos de diferentes formulações comerciais de glyphosate sobre estirpes de Bradyrhizobium. Planta Daninha 22: 293-299.

SOARES MA, BATISTA JD, ZANUNCIO JC, LINONETO J AND SERRÃO JE. 2011. Ovary development, 
egg production and oviposition for mated and virgin females of the predator Podisus nigrispinus (Heteroptera: Pentatomidae). Acta Sci Agron 33: 597-602.

SOUZA GK, PIKART TG, ZANUNCIO TV, WILCKEN CF, SERRÃO JE AND ZANUNCIO JC. 2014. Reproductive tract histology of Thaumastocoris peregrinus (Hemiptera: Thaumastocoridae). Ann Entomol Soc Am 107: 853-857.

SUCHAIL S, GUEZ D AND BELZUNCES LP. 2001. Discrepancy between acute and chronic toxicity induced by imidacloprid and its metabolites in Apis mellifera. Environ Toxicol Chem 20: 2482-2486.
TORRES JB, ZANUNCIO JC AND MOURA MA. 2006. The predatory stinkbug Podisus nigrispinus: biology, ecology and augmentative releases for lepidoperan larval control in Eucalyptus in Brazil. Biocont News Infor 27: 1-18.

YU S. 1988. Selectivity of insecticides to the spinned soldier bug (Heteroptera: Pentatomidae) and its lepidopterous prey. J Econ Entomol 81: 119-122.

ZANUNCIO TV, SERRÃO JE, ZANUNCIO JC AND GUEDES RNC. 2003. Permethrin-induced hormesis on the predator Supputius cincticeps (Stål, 1860) (Heteroptera: Pentatomidae). Crop Prot 22: 941-947. 